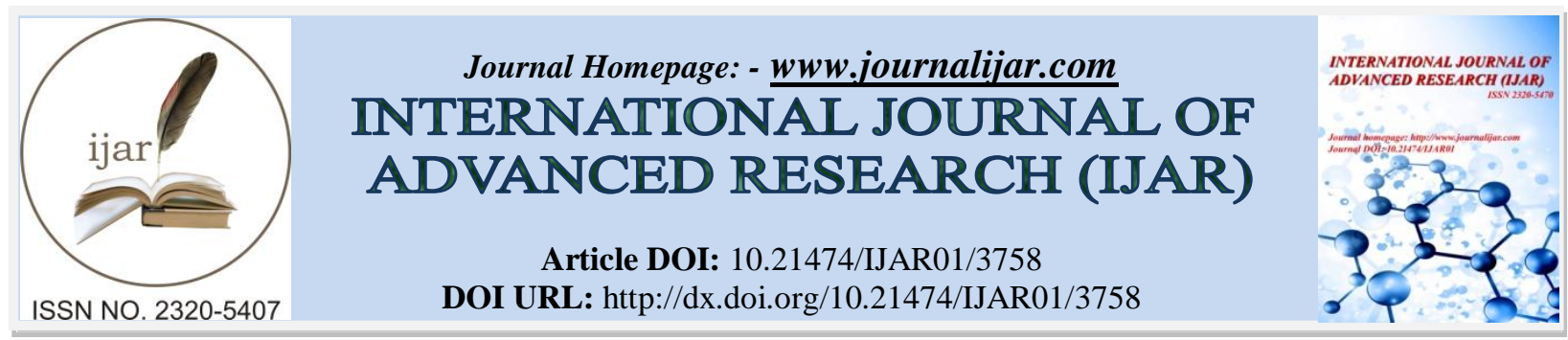

RESEARCH ARTICLE

\title{
HUMAN RESOURCES INFORMATION SYSTEMS AND THEIR IMPACT ON THE EFFECTIVENESS OF ORGANIZATIONAL CHANGE MANAGEMENT-APPLIED STUDY ON THE JORDAN INSURANCE COMPANIES.
}

\author{
Abdel Mutti Assaf, Aysarkhashman, FerasAlzubi and Ayyoub Alsawalhah. \\ Department of Management, Faculty of Finance and Business Administration,the World Islamic Sciences \& \\ Education University, Jordan.
}

\section{Manuscript Info}

\section{Manuscript History}

Received: 16 January 2017

Final Accepted: 13 February 2017

Published: March 2017

Key words:-

information systems, human resources information systems, organizational change management, Jordanian

Insurance companies.

\begin{abstract}
The aim of this study is to investigate the effect of human resources information systems on the effectiveness of organizational change management,applied study on Jordanian insurance companies. The study concluded with the following results: there is a correlation relationship between the training on system and the effectiveness of organizational change management, the training on system explained $19.9 \%$ of the variation in the effectiveness of organizational change management, the availability of technical support explained $37.8 \%$ of the variation in the effectiveness of organizational change, the availability of technical support explained $55.1 \%$ of the variation in the effectiveness of organizational change, the availability of technical support explained $57.8 \%$ of the variation in the effectiveness of organizational change. The multiple regression results showedthat training on the system has no significant effect on the effectiveness of organizational change, while there was a significant effect of (availability of technical support, senior management support, availability of infrastructure) on the effectiveness of organizational change. The study recommended with the following: develop the capacity of workers and trained them on human resources information systems requirements, put a fair system of incentives to encourage innovation and creativity process, develop infrastructure and technological development, and there is a need to be updated with the developments existing in the world, update software and deal with the reliable one, benefit from the experiences of other insurance companies regarding human resources information systems, management of change resistance and use scientific means.
\end{abstract}

Copy Right, IJAR, 2017,. All rights reserved.

\section{Introduction:-}

Organizational success and management of the knowledge economy is heavily dependent today on the performance of Human Resources Management (HRM) (Lippert and Swiercz, 2005; Troshani et al, 2011). The human resources management (HRM) recently changed to focus on the exchange of knowledge and strategic analysis of the workforce, andits contribution significantly developed widely in the strategic management of the organization and adaptation with the surrounding forces of change that have high impact on the management of its resources and 
maximize the return of them (Rodriguez and Ventura, 2003; Troshani et al., 2011).Therefore, the organizations with various forms seek today to take advantage of all what possesses of resources, potential and abilities to face the developments and challenges that determine their relationship with its customers and affect its position in the market, so there is a new direction to increase the effectiveness of the management of human resources by relying on human resources information systems (Ball, 2001; Lippert and Swiercz, 2005; Troshani, et al., 2011).To do so, the Jordanian insurance companies must use human resources information systems in order to adapt with the surrounding forces of change, and to achieve and build competitive advantage, and this can provide quick access to the customer and meet his/her expectations.

\section{Problem Statement:-}

The change management in Jordanian Insurance companies is one of the most important research areas, as it is a tool that affects the reasons for its survival and development of its ability to adapt with the surrounding environmental forces that have effective impact on their ability in leading markets. the human resources information systems interest is one of the strategies that must be taken into account in this aspect, the researcher thinks that there is a lack of awareness in the role of human resources information systems in the organizational change management in the Jordanian insurance companies, so they must develop their human resources systems in line with the size of change that occurred in their environment.

\section{Study Objectives:-}

$>$ Know the reality of human resources information systems in the Jordanian insurance companies.

$>$ Know the reality of change management in the Jordanian insurance companies.

$>$ Know the areas of use of human resources information systems in the Jordanian insurance companies.

$>$ Know the effect of use of human resources information systems on the effectiveness of change management in the Jordanian insurance companies.

\section{Study Importance:-}

The importance of the study stems out from the importance of human resources information systems and their role in the development of the capacity of workers and raise their readiness for the best use of the resources, and this requires good change management and adapting with that change to achieve the goals and raise the organization ability to deal with the forces of change in the internal and external environment, and this assures that organizations must respond to rational demanding which is based on the principle of rational view to achieve the desired benefits while achieving stakeholder satisfaction. Also, the applied importance of this study stems out of the importance of the researched sector, the Jordanian Insurance companies, which employs a large number of staff and they are reliable sector to make partnership with government agencies in the development and employment and in running the economic resources sectors. The activation of the use of human resources information systems in the Jordanian insurance companies will raise their efficiency, so that the right choice for workers will raise their abilities and their knowledge and develop attitudes, and provide data and knowledge by the required ways.

\section{Hypotheses:-}

first hypothesis: There is no statistically significant effect of human resources information systems represented by (training on system, availability of technical support, senior management support, availability of infrastructure ) on the effectiveness of change management (technological change, cultural change, change in the organizational structure) in Jordanian insurance companies.

\section{The first hypothesis is divided into the following sub-hypotheses:}

$>$ First sub hypothesis: There is no statistically significant effect of (the training on system) on the effectiveness of organizational change in the Jordanian insurance companies.

$>$ Second sub hypothesis: There is no statistically significant effect of viability of technical support on the effectiveness of organizational change in the Jordanian insurance companies.

$>$ Third sub hypothesis: there is no statistically significant effect of senior management support on the effectiveness of organizational change in the Jordanian insurance companies.

$>$ Fourth sub hypothesis: There is no statistically significant effect of the availability of infrastructure on the effectiveness of organizational change in the Jordanian insurance companies. 


\begin{tabular}{|c|c|}
\hline Study Model Variables & \\
\hline $\begin{array}{l}\text { Independent Variable } \\
\text { Human Recourses Information System } \\
\text { 1-availability of technical support } \\
\text { 3- Senior management support } \\
\text { 3- Availability of infrastructure }\end{array}$ & $\begin{array}{l}\text { Dependent Variable } \\
\text { Effectiveness of Management of } \\
\text { Organizational Change } \\
\text { 1- effectiveness of technological change } \\
\text { 2- effectiveness of cultural change }\end{array}$ \\
\hline
\end{tabular}

Sub-variables for human resources information systems have been identified by study of (Abu Obeilh ,2010) (Alkdah and Alkarasnih, 2008), the variables of the effectiveness of change management were determined by study of (Anzi 2013).

\section{Previous Literature:-}

\section{Human resources information systems:-}

The use of technology in the field of human resources has significantly and continuously expanded and therefore the human resources management activities changed at the senior, middle or lower management level (Mathis and Jackson, 2010).human resources information systems have evolved since 1960 (Lederer, 1984), the surveys carried out by the study of (Ball , 2001) indicated that $60 \%$ of Fortune Companies used human resources information system to support their daily operations of human resources management (Kovach et al., 2002).With the beginning of the nineties of the past century, human resource management practices have become more complex and there is great pressure to achieve corporate objectives related to improving general performance, and therefore human resources information systems (HRIS) have evolved to use expert information, which includes analytical tools to support the decision-making process in managing human capital (Ostermann, Staudinger \& Staudinger, 2009). The human resource planning process makes the process of follow-up easier regarding gaps in the labor force, either quantitative or qualitative or planning to determine the needs of the labor force in the future and all that with the help of knowledge systems used by human resources (Dessler, 2005 ). The human resources information systems accelerate the formulation and implementation of effective human resources management activities, which include personnel management, payroll administration, and monitoring daily work attendance, skills development, medical history, performance appraisal, training and development, human resources planning, recruitment and career planning, negotiations and so on (Singh et al., 2011).Human resources information system defined as these systems which are based on the technology used for the acquisition, storage, processing, analysis, retrieval and distribution of relevant information on the human resources of the organization (Tannenbaum, 1990). Also it is defined as the integrated system used to collect, store and analyze information related to human resources in the organization by using the necessary data and computer applications and the hardware and software (Hendrickson, 2003). The Human Resources Information System (HRIS) is one of the most important management information systems that contributes to the goals and strategies of the organization related to the management of human resources and increasing their capabilities (Kavangah et al, 2002). (Pyburn, 1983) indicated that (HRIS) is becoming increasingly important for the successful implementation of the company's strategy, whilst (Tanriverdi, 2006) indicated that ((HRIS) is a strategic organizational resource.The human resources information systems have an essential and effective role in achieving the organization's objectives, and therefore they must provide a number of basic requirements interconnected and integrated with each other, and those requirements are as follows : (Almagribi, 2009, p. 352 ).

\section{Administrative requirements:-}

All organizations seek access to its goal and achieve the desired goals of performance, so the organization management is primarily responsible for identifying those goals and the role to be played by human resources information systems, so the organizations has to train workers on the system and to provide all the requirements relating to infrastructure. The system design requires cooperation between different organization and human resources management departments, and provision of all requirements of the multiple resources, and vigorous follow up for all its elements and its components to ensure efficiency and effectiveness in its performance, and that system must consider to the need of beneficiaries regarding information and statements. 


\section{Technological requirements:-}

The success of the human resources system in the implementation of the tasks entrusted to it depends on what is owned by the organization of devices and machinery and infrastructure within the limits of their capabilities, and the ability of employees to manage and operate those machines by what is available of expertise and technical skills. the data and information provided by the system are extremely important which, therefore, must be handled with absolute secrecy, and the organization management should design an integrated system that considers to maintenance and safety, as they must be characterized by interdependence and integration to utilize them more effectively.

\section{Economic requirements:-}

The human element is the most important requirements in the success of the human resources information system, as the optimum utilization of the personnel, and training them on the system skills will contribute in achieving the desired goals, and will reducethe costs, as the time factor will effect on the preparation and design that is based on clear and sound principles.

\section{Social requirements:-}

The fact that the human resources information system depends on the amount of joint cooperation between human resources management and beneficiaries of the system on one hand, and between workers in the organization and the various departments on the other hand, as this cooperation results will provide the necessary information, and to help them to extract data necessary, and to encourage positive behavior for employees and beneficiaries of the system which makes it easy to take advantage of its results and outputs.

\section{The effectiveness of organizational change:-}

The application of the regulatory change is necessary for organizations in order to compete in the constantly changing business environment. The rapid development of information and communication technology has made many organizations to seek creating ways and ideas for new and innovative solutions to improve existing products and strategy of its operations and its technological system and all this called organizational change, which requires acceptance of its workers in the framing positive behavior, which will inevitably lead to change in the organization (Tan and Nasurdin, 2010). Change management: is a means of planning, implementation and follow-up in the processes of change at the institutional and personal level, and includes a revolutionary change in the management of new projects and developmental changes in theorganization structure (Frans, 2010). Change management defined as the effective management of change that practice by executive, managers and employees by using technology and organizational resources. (Korir, Mukotive, 2012).

The areas of change in organizations:-

It is the most influential external power in the organization than the internal power because of its broad scope and difficulty of predicting their dimensions, and also because of rapid changes in the environment in which the organizationswork.It turned out that there is a significant increase in competition between companies, especially after the emergence of the current globalization and the accession of many countries to the World Trade Organization (WTO)

These global changes have impacted heavily on the methods and patterns of management in the organizations, and thus they made them to move from the static central and bureaucratic systems to a more flexible system which fit with the nature of the global economic transformations system, and there is a needto change as a strategic choice (Sawalhah, et al 2015).The legal environment has also played a big role, represented by state intervention in economic and social activity and legal environment that lies in the change of laws or amended legislation as these impose restrictions or create opportunities, such as changes in fiscal and monetary government policy (Sawalhah et al, 2015).The technological environment is the most important source for change, where the latest technical development in industrialized countries made parallel change in the labor force structures, and the organizational structures moved from the traditional pyramid shape to the knowledge organizations and not routine business organizations, and consequently there is a change in training curricula and change in performance standards. The most important technological change that drives to change is the advancement in transportation and communication, which overcomes the border that was between the countries, and the aspects of accelerated technological development in digital equipment and machinery. The information revolution appears through information and communication technology (Sawalhah et al, 2015). Organizations also witnessed a dramatic change in values, attitudes and behaviors of individuals, customers and suppliers, culture surrounding environment do not only 
affects the behavior of employees and their way of dealing, but this culture is reflected in the existing structure and pattern of the prevailing management and communication systems and information, and people's ways in problemsolving and decision-making, also it effects on customers' trends particularly in demand ,product design ,marketing mix and methods of dealing with customer (Sawalhah, et al 2015).

\section{Hypotheses Testing;-}

first hypothesis: There is no statistically significant effect of human resources information systems represented by (training on system, availability of technical support, senior management support, availability of infrastructure ) on the effectiveness of change management (technological change, cultural change, change in the organizational structure) in Jordanian insurance companies.

The first hypothesis is divided into the following sub-hypotheses:-

First sub hypothesis: There is no statistically significant effect of (the training on system) on the effectiveness of organizational change in the Jordanian insurance companies.

Table 1:- Simple regression of the first hypothesis.

\begin{tabular}{|c|c|c|c|c|c|c|c|c|c|c|}
\hline \multirow{3}{*}{$\begin{array}{l}\text { Dependent } \\
\text { variable } \\
\text { Effectiveness } \\
\text { of } \\
\text { organization } \\
\text { change }\end{array}$} & \multicolumn{2}{|c|}{ Model Summary } & \multicolumn{3}{|l|}{ ANOVA } & \multicolumn{5}{|c|}{ Coefficients } \\
\hline & & $\begin{array}{l}\mathrm{R} \\
\text { square }\end{array}$ & $\begin{array}{l}\text { Adjusted } \\
\text { R Square }\end{array}$ & DF & SIG & $\begin{array}{l}\text { VAR } \\
\text { Training } \\
\text { on system }\end{array}$ & $\beta$ & $\begin{array}{l}\text { Std. } \\
\text { Error }\end{array}$ & $\mathrm{T}$ & SIG \\
\hline & 0.478 & 0.199 & 105.756 & 1 & 0.000 & 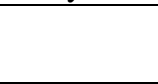 & 0.478 & 0.033 & 11.096 & 0.000 \\
\hline
\end{tabular}

The table above shows that there is a strong correlation between the training on system and the effectiveness of management of organizational change, the training on system explained $19.9 \%$ of the variation in the effectiveness of organizational change, as (F) value is statistically significant on the test.

Based on the results, we accept the alternative hypothesis:-

There is statistically significant effect of (the training on system) on the effectiveness of organizational change in the Jordanian insurance companies

Second sub hypothesis: There is no statistically significant effect of availability of technical support on the effectiveness of organizational change in the Jordanian insurance companies.

Table 2:- Simple regression of the second hypothesis.

\begin{tabular}{|c|c|c|c|c|c|c|c|c|c|c|}
\hline \multirow{3}{*}{$\begin{array}{l}\text { Dependent } \\
\text { variable } \\
\text { Effectiveness } \\
\text { of } \\
\text { organization } \\
\text { change }\end{array}$} & \multicolumn{2}{|c|}{ Model Summary } & \multicolumn{3}{|l|}{ ANOVA } & \multicolumn{5}{|l|}{ Coefficients } \\
\hline & $\mathrm{R}$ & $\begin{array}{l}\mathrm{R} \\
\text { square }\end{array}$ & $\begin{array}{l}\text { Adjusted } \\
\text { R Square }\end{array}$ & $\overline{\mathrm{DF}}$ & SIG & $\begin{array}{l}\text { VAR } \\
\text { availability } \\
\text { of technical } \\
\text { support }\end{array}$ & $\beta$ & $\begin{array}{l}\text { Std. } \\
\text { Error }\end{array}$ & $\mathrm{T}$ & SIG \\
\hline & 0.625 & 0.378 & 351.258 & 1 & 0.000 & & 0.625 & 0.033 & 18.152 & 0.000 \\
\hline
\end{tabular}

The table above shows that there is a strong correlation between the availability of technical support and effectiveness of organizational change management, the availability of technical support explained $37.8 \%$ of the variation in the effectiveness of organizational change, as $(F)$ value is statistically significant on the test.Based on the results, we accept the alternative hypothesis:There is statistically significant effect of(availability of technical support) on the effectiveness of organizational change in the Jordanian insurance companies.

Third sub hypothesis: there is no statistically significant effect of senior management support on the effectiveness of organizational change in the Jordanian insurance companies.

Table 3:- Simple regression of the third hypothesis.

\begin{tabular}{|c|c|c|c|c|c|c|c|c|c|c|}
\hline \multirow{3}{*}{$\begin{array}{l}\text { Dependent } \\
\text { variable } \\
\text { Effectiveness } \\
\text { of } \\
\text { organization } \\
\text { change }\end{array}$} & \multicolumn{2}{|c|}{ Model Summary } & \multicolumn{3}{|l|}{ ANOVA } & \multicolumn{5}{|l|}{ Coefficients } \\
\hline & $\mathrm{R}$ & $\mathrm{R}$ square & $\begin{array}{l}\text { Adjusted R } \\
\text { Square }\end{array}$ & DF & SIG & $\begin{array}{l}\text { VAR } \\
\text { Senior } \\
\text { management } \\
\text { support }\end{array}$ & $\beta$ & $\begin{array}{l}\text { Std. } \\
\text { Error }\end{array}$ & $\mathrm{T}$ & SIG \\
\hline & 0.732 & 0.551 & 525.237 & 1 & 0.000 & & 0.732 & 0.031 & 21.103 & 0.000 \\
\hline
\end{tabular}


The table above that there is a strong correlation between the seniormanagement support and the effectiveness of organizational change management, the technical support explained $55.1 \%$ of the variation in the effectiveness of organizational change, as $(\mathrm{F})$ value is statistically significant on the test.Based on the results, we accept the alternative hypothesis:There is statistically significant effect of senior management support on the effectiveness of organizational change in the Jordanian insurance companies.

Fourth sub hypothesis: There is no statistically significant effect of the availability of infrastructure on the effectiveness of organizational change in the Jordanian insurance companies.

Table 4:- Simple regression of the fourth hypothesis

\begin{tabular}{|c|c|c|c|c|c|c|c|c|c|c|}
\hline \multirow{3}{*}{$\begin{array}{l}\text { Dependent } \\
\text { variable } \\
\text { Effectiveness } \\
\text { of } \\
\text { organization } \\
\text { change }\end{array}$} & \multicolumn{2}{|c|}{$\begin{array}{l}\text { Model } \\
\text { Summary }\end{array}$} & \multicolumn{3}{|l|}{ ANOVA } & \multicolumn{5}{|l|}{ Coefficients } \\
\hline & $\mathrm{R}$ & $\begin{array}{l}\mathrm{R} \\
\text { square }\end{array}$ & $\begin{array}{l}\text { Adjusted } \\
\text { R Square }\end{array}$ & DF & SIG & $\begin{array}{l}\text { VAR } \\
\text { Availability } \\
\text { of } \\
\text { infrastructure }\end{array}$ & $\beta$ & $\begin{array}{l}\text { Std. } \\
\text { Error }\end{array}$ & $\mathrm{T}$ & SIG \\
\hline & 0.775 & 0.578 & 525.237 & 1 & 0.775 & & 0.775 & 0.025 & 23.144 & 0.000 \\
\hline
\end{tabular}

The table above shows that there is a strong correlation between the availability of infrastructure and effective management of organizational change, the technical support explained $57.8 \%$ of the variation in the effectiveness of organizational change, as $(F)$ value is statistically significant on the test.

Based on the results, we accept the alternative hypothesis says:

There is statistically significant effect of the availability of infrastructure on the effectiveness of organizational change in the Jordanian insurance companies.To test the main first hypothesis, we used multiple regressions as follows:

Table 5:- Multiple regressions for fourth hypothesis

\begin{tabular}{|c|c|c|c|c|c|c|c|c|c|c|}
\hline \multirow{3}{*}{$\begin{array}{l}\text { Dependent } \\
\text { variable } \\
\text { Effectiveness } \\
\text { of } \\
\text { organization } \\
\text { change }\end{array}$} & \multicolumn{2}{|c|}{$\begin{array}{l}\text { Model } \\
\text { Summary }\end{array}$} & \multicolumn{3}{|l|}{ ANOVA } & \multicolumn{5}{|l|}{ Coefficients } \\
\hline & $\mathrm{R}$ & $\begin{array}{l}\mathrm{R} \\
\text { square }\end{array}$ & $\begin{array}{l}\text { Adjusted } \\
\text { R Square }\end{array}$ & $\mathrm{DF}$ & SIG & VAR & $\beta$ & $\begin{array}{l}\text { Std. } \\
\text { Error }\end{array}$ & $\mathrm{T}$ & SIG \\
\hline & 0.805 & 0.725 & 175.232 & 4 & 0.000 & $\begin{array}{l}\text { Training on } \\
\text { system }\end{array}$ & -0.075 & 0.025 & $0.725-$ & 0.441 \\
\hline & & & & & & $\begin{array}{l}\text { Availability } \\
\text { of technical } \\
\text { support }\end{array}$ & 0.169 & 0.047 & 4.425 & 0.000 \\
\hline & & & & & & $\begin{array}{l}\text { Senior } \\
\text { management } \\
\text { support }\end{array}$ & 0.118 & 0.041 & 3.045 & 0.000 \\
\hline & & & & & & $\begin{array}{l}\text { Availability } \\
\text { of } \\
\text { infrastructure }\end{array}$ & 0.335 & 0.036 & 6.321 & 0.000 \\
\hline
\end{tabular}

The table above show that the correlation coefficient $(0.805)$, indicating to a strong correlation, and that the impact of dimensions of human resources information systems on the dependent variable (effectiveness of organizational change) is a statistically significant, according to F value, and R square, it is indicated that $72.5 \%$ of change in the effectiveness of organizational change was due to the human resources information systems,. The training on the system has no statistically significantimpact, while the other variables have statistically significant impact. 


\section{Results and Recommendations:- \\ Results:-}

Based on the field study and analysis of survey data and the variables the study the following results was drawn:

1. There is a strong correlation between the training on system and the effectiveness of organizational change management the training on the system explained $19.9 \%$ of the variation in the effectiveness of organizational change, as $(\mathrm{F})$ value is statistically significant on the test.

2. There is a strong correlation between the availability of technical support and effectiveness of management of organizational change, the availability of technical support explained $37.8 \%$ of the variation in the effectiveness of organizational change, as $(\mathrm{F})$ value is statistically significant on the test.

3. There is a strong correlation between the support of senior management and the effectiveness of management of organizational change, the availability of technical support explained $55.1 \%$ of the variation in the effectiveness of organizational change, as $(\mathrm{F})$ value is statistically significant on the test.

4. There is a strong correlation between the availability of infrastructure and effectiveness of organizational change, the availability of infrastructure explained $57.8 \%$ of the variation in the effectiveness of organizational change, as $(\mathrm{F})$ value is statistically significant on the test.

5. Multiple Regression Results showed that training on the system has a statistically significant on the effectiveness of organizational change while there was a statistically significant effect of (availability of technical support, senior management support availability of infrastructure) on the effectiveness of organizational change.

\section{Recommendations:-}

1. Develop the capacity of workers and training them on human resources information systems requirements.

2. Put a fair system of incentives to encourage innovation and creativity process.

3. Develop Technological infrastructure and the to keep up with the developments in the world

4. Update software and deal with them reliably.

5. Take advantage from otherinsurance company'sexperiences with respect to human resources information systems.

\section{Reference:-}

1. Abu Obeilh Faisal Abdullah, 2010, the impact of the application of human resources information systems on the effectiveness of human resources management, In the Jordanian Public Security Department, Master Thesis unpublished ,Mutah University,

2. Almagribi,, Abdel-Hamid (2002). Management information systems. Arab Republic of Egypt, Mansoura: Modern Library.

3. Al Sawalhah, et al (2015),"Impact of Transformational Leadership in Reducing Employees Resistance to Organizational Change"International Journal of Business and Social Science Vol. 6, No. 12.

4. Anzi, YousefSaleh (2013), the impact of change management on the effectiveness of public shareholding companies in the State of Kuwait, a message Unpublished Master, Middle East University.

5. Ball, K.S. (2001). The use of human resource information systems: a survey. Personnel Review, 30(6), 677-693.

6. Dessler, Gary (2005). Human Resource Management (13th ed.). Upper Saddle River, $\quad$ N.J.: $\quad$ Prentice Hall.

7. Frans, Peter. 2010. Phases in Change Processes. Trimitra Consultants. www.trimitra.com/articles/change_02.htm.

8. Hendrickson, A. R. (2003) Human Resource Information Systems: Backbone Technology of Contemporary Human Resources, Journal of Labor Research, 24/3, 381-394.

9. Kavanagh, M. J., Thite, M., \& Johnson, R. D. (2002). Human resource information systems : basics, applications, and future directions (2nd ed.).United States of America: Thousand Oaks : SAGE.

10. Korir J, Mukolive E, et-al (2012). Change Management Effects on Hotel Performance: Journal of social science tomorrow vol1, No.8.

11. Lederer, A. L. (1984). Planning and developing a human resource information system.The Personnel Administrator, 29(8), 27-39.

12. Lippers, S. K., \&Swiercz, P. M. (2005). Human resource information systems (HRIS) \& technology trust. Journal of Information Science, 31(5), 340-353.

13. Mathis R, Jackson R. (2010). Human Resource Management, Cengage Publishing 
14. Ostermann, H., Staudinger, B., \& Staudinger, R. (2009). Benchmarking human resource information systems. In T. Coronas \& M. Oliva (Ed.), Encyclopedia of Human Resources Information Systems: Challenges in EHRM (pp. 92-101). Hershey, PA: IGI Global.

15. pyburn, Philip J. (1983) "Linking the MIS Plan with Corporate Strategy: An Exploratory Study". MIS Quarterly. 1-13. Full-text [online]

16. Rodriguez, J. M., \& Ventura, J., (2003). Human resource management systems \& organizational performance: an analysis of the Spanish manufacturing industry. International Journal of Human Resource Management, 14(7).

17. Singh, H. P., Jindal, S., Samim, S. A. (2011), "Role of Human Resource Information Systems in Banking Industry of Developing Countries, The First International Conference on Interdisciplinary Research and Development, 31 May - 1 June 2011, Thailand

18. Tan, C. L. and Nasurdin, A. M. (2010), - Human resource management practices and organizational innovation: An empirical study in Malaysiall, Journal of Applied Business Research, Vol.2, No.4, pp. 105-115.

19. Tanriverdi, H. 2005. "Information Technology Relatedness, Knowledge Management Capability, and Performance of Multibusiness Firms," MIS quarterly (29:2), pp. 311- 334.

20. Tannenbaum, S.I. (1990). Human Resource information Systems: User Group Implications. Journal of Systems Management. 41(1), 27-32.

21. Troshani, I., Jerram, C., \&Rao, S. (2011). Exploring the public sector adoption of HRIS. Industrial Management and Data Systems, 111(3), 470-488. 